\title{
Dualization and Electoral Realignment
}

\author{
Silja Häusermann* \\ University of Zurich \\ ${ }^{\star}$ Corresponding author. Email: silja.haeusermann@ipz.uzh.ch
}

(Received 19 June 2018; accepted 24 August 2018; first published online 12 November 2019)

\begin{abstract}
The growing research on post-industrial labor market inequality bears a strong-yet widely misunderstood-relevance for the literature on electoral realignment. In this contribution, I contend that the assumption of "labor market outsiders" being equal to "globalization/modernization losers" is largely mistaken. Rather, atypical work and unemployment is most widespread among service workers, whose primary electoral choice is to abstain from voting. This implies that the ongoing reconfiguration of European party systems-through the rise of right-wing populist parties-is driven by skilled and routine workers in the manufacturing sector (the traditional "insiders"). Hence, the rise of right-wing populist parties reflects a political mobilization of the formerly well-protected industrial working class, rather than of labor market outsiders.
\end{abstract}

Keywords: Comparative Political Economy; Comparative Politics: Industrialized Countries; Comparative Politics: Political Behavior; Political Participation and Turnout; Political Parties and Interest Groups

In this short contribution, I argue that the growing research on post-industrial labor market inequality bears a strong-yet widely misunderstood-relevance for the comparative politics literature on the transformation of political party systems. More specifically, I contend that the assumption of "labor market outsiders" being equal to "globalization/modernization losers"-and therefore constituting the core electorate of right-wing populist parties-is largely mistaken. Rather, atypical work and unemployment is most widespread among service workers, whose primary electoral choice is to abstain from voting.

This implies that the fundamental and still ongoing reconfiguration of European party systems - through the rise of right-wing populist parties-is actually driven by workers in the manufacturing sector (the traditional "insiders"), rather than by labor market outsiders. They seem to vote for right-wing populist parties not primarily for reasons of labor market vulnerability, but rather because of a fear of relative decline. Hence, the rise of right-wing populist parties should not be interpreted in simple class-conflict terms as a mobilization of precarious labor market outsiders against the more privileged. In the light of the widespread electoral abstention of labor market outsiders, a crucial question for European party politics will be whether this growing group of voters will be mobilized electorally in the future, and if yes, by whom. Linking the study of labor market inequality more closely with research on changing party systems could provide the former with a broader relevance beyond comparative political economy, and the latter with a sounder micro-foundation.

The goal of this contribution is conceptual: it discusses both the main concepts of labor market vulnerability examined in political economy, as well as the main concepts of globalization/modernization losers proposed in the party literature. The paper then operationalizes these concepts empirically and shows that the losers from globalization are not congruent with labor market outsiders. In a second step, the paper looks at electoral choice. 


\section{Labor market inequality and new electoral cleavages}

Labor Market Change in Post-industrial Societies Transforms Electoral Politics. At least two important strands of recent research would subscribe to this statement, but they approach it from opposite sides and, to date, almost entirely separately: the first strand of literature is the one on dualization and increasing labor market inequality, which is under close examination in this symposium. For about a decade now, scholars in political economy have been theorizing the political determinants and effects of growing inequality in the distribution of labor market risk between insiders and outsiders. When addressing the political relevance of labor market inequality, this literature usually takes a micro-level approach, starting from the effects of risk exposure on political preferences of individuals, and then moving upwards towards processes of preference mobilization, aggregation and-though rarely-representation (e.g., Häusermann 2010; Rehm 2011; Lindvall and Rueda 2014). However, the literature on dualization, to an extent, got stuck in questions of conceptualization and measurement at the micro-level, thereby losing its focus on the wider political impact of labor market inequality.

The second strand of literature that would subscribe to the above statement is not in political economy, but in comparative politics. Over the past two decades, a hugely influential literature has demonstrated that electoral politics and party systems in Europe have been deeply transformed by the emergence of a socio-cultural dimension of political mobilization and conflict, which cross-cuts the traditional, economic left-right divide (notably Kitschelt 1994; Hooghe, Marks and Wilson 2002; Kriesi et al. 2008; Bornschier 2010). The (few) studies in this literature, which actually do investigate the micro-level foundation of this new divide argue that the continuously growing "traditional-authoritarian-nationalist" pole of this dimension (in the words of Hooghe et al. 2002) is built on the votes of "losers" of either modernization or globalization, whose vote choice can be explained to a large extent with reference to economic risk and hardship (Betz 1994; Kitschelt 1997; Kriesi et al. 2008). Hence, this literature indeed takes a keen interest in labor market risk, but it adopts a top-down approach when studying it, starting from changes in the party system and then moving downwards towards socio-structural potentials. Consequently, the micro-foundation of electoral realignment has remained an Achilles heel of the literature on electoral realignment.

These two strands of literature have evolved almost entirely separately. Where implicit or explicit links between processes of labor market dualization and electoral realignment are made at all, the most straightforward assumption is that globalization/modernization losers are roughly congruent with labor market outsiders, and therefore, they constitute the key electorate of right-wing populist parties (e.g., Lubbers et al. 2002; Mughan et al. 2003; King and Rueda 2008). However, this shortcut may well be too rushed. First, labor market risk is not a synonym of "cheap labor," as it is a mechanism of stratification that is distinct from income (see e.g., Rehm et al. 2012; Häusermann et al. 2015). Second, labor market vulnerability affects various segments of the working class to very different extents, with some of them being protected (insiders) and others exposed (outsiders). The implications of this incongruence between the "working class" and "outsiders" for political mobilization and electoral representation have remained direly underexplored. Regarding research on labor market dualization and insider-outsider divides, the focus has been on individual preferences (e.g., Burgoon and Dekker 2010; Rehm et al. 2012; Häusermann et al. 2015), whereas the political aggregation and representation of these preferences, or the link between labor market risk and party choice have received much more scant attention.

Hence, comparative politics finds itself in a situation where different strands of theorizing and research investigate the same topic-i.e., the electoral behavior and mobilization of the "losers" of post-industrial economies-almost entirely separately, with substantial costs in terms of conceptual confusion and limited comparability of findings. Linking insights on dualization and electoral realignment may provide us with a sounder micro-foundation regarding the motivations that drive these processes of realignment. 
In terms of starting an exploration of this question, I provide in the following an aggregated account of how labor market risk relates to the most prominent conceptualizations of globalization/modernization losers, and to party choice.

\section{Comparing labor market outsiders and losers of globalization or modernization}

How widespread is unemployment, temporary employment and part-time employment among losers (as opposed to winners) of globalization or modernization?

The definition and operationalization of globalization losers and modernization losers are contested in the literature. I use here the three main definitions available. Contributions in the field of International Political Economy (focused on globalization) tend to characterize as losers of globalization low-skilled workers in jobs that are exposed to international economic competition (e.g., Mughan et al. 2003). I use here the operationalization proposed by Walter and Rommel (2017) based on skill and the offshoreability of specific occupations. While some occupations can be delocalized in other countries, other occupations can be characterized as "sheltered." I present the low- skilled sheltered here as relative globalization winners for the purpose of comparison to globalization losers.

In contrast, the comparative political economy literature focuses rather on occupational structural change as drivers of labor market changes and hence tends to privilege the term modernization losers. Interestingly, two distinct occupational groups can be conceptualized as primary losers of structural change. Given massive deindustrialization and skill-biased technological change (Oesch 2013), manual workers in manufacturing must be considered the main losers of structural change. This group corresponds to the traditional industrial blue-collar working class. At the same time, however, many European countries have seen since the 1990s the emergence of a growing service sector working class (Oesch 2013), which tends to be less unionized and whose contracts tend to be less well protected than the work contracts of the traditional industrial working class. Low-skilled service sector workers, even though they work in a growing occupational sector, can thus also be seen as losers of modernization. Hence, I look at both the routine service workers and the routine/skilled manual workers as possible losers of modernization. In contrast, I conceptualize high-skilled service sector workers ("socio-cultural professionals," Oesch 2013) as modernization winners in terms both of a growing occupational sector and high levels of education, which are in stronger demand in postindustrial labor markets. ${ }^{1}$

Table 1 displays the group-specific rates of unemployment (in the past 5 years) and atypical employment for all respondents of the European Social Survey (ESS) waves 1-5 in Western Europe. It highlights all groups that are affected more strongly than average by these three main forms of post-industrial labor market risk.

The first finding from this simple cross-tabulation is that labor market outsiders and globalization losers are clearly two distinct groups. Low-skilled workers in offshoreable jobs are not affected more strongly by labor market vulnerability than the average population. The distinction between low-skilled offshoreable and sheltered occupations does not coincide with objective labor market risks. The correspondence between labor market risk and losers/winners from modernization is stronger, but also far from perfect. Both service workers and manufacturing workers are more strongly affected by unemployment than modernization winners. But in terms of atypical work contracts, we see that labor market vulnerability is not confined to the working class. High-skilled service workers have shares of temporary and part-time contracts that are comparable to those of the low-skilled workers in the service sector.

Table 1 clearly shows that routine service workers are most strongly and most negatively affected by labor market risk in post-industrial economies. Hence, if we relate the concept of labor market outsiders to occupational classes, we must think primarily of the low-skilled service class workers as outsiders, rather than the traditional blue-collar working class.

${ }^{1}$ I follow Bornschier and Kriesi (2013) and Oesch (2013) in operationalizing them in terms of occupational classes. 
Table 1. Unemployment and Atypical Employment among Winners and Losers of Globalization and Modernization

\begin{tabular}{|c|c|c|c|c|c|}
\hline & \multirow{2}{*}{$\begin{array}{c}\text { Globalization } \\
\text { losers } \\
\text { Low-skilled } \\
\text { offshoreable }\end{array}$} & \multirow{2}{*}{$\begin{array}{l}\text { Globalization } \\
\text { winners } \\
\text { Low-skilled } \\
\text { sheltered }\end{array}$} & \multicolumn{2}{|c|}{ Modernization losers } & \multirow{2}{*}{$\begin{array}{c}\text { Modernization } \\
\text { winners } \\
\text { High-skilled service } \\
\text { workers }\end{array}$} \\
\hline & & & $\begin{array}{l}\text { Routine } \\
\text { service } \\
\text { workers }\end{array}$ & $\begin{array}{l}\text { Routine/skilled } \\
\text { manual workers }\end{array}$ & \\
\hline $\begin{array}{l}\text { Ever unemployed over } \\
\text { the past five years }\end{array}$ & 10.28 & 11.24 & 18.74 & 16.67 & 8.02 \\
\hline Average & 11.76 & 11.76 & 11.76 & 11.76 & 11.76 \\
\hline Deviation & -1.48 & -0.52 & 6.98 & 4.91 & -3.74 \\
\hline Temporary contract & 10.1 & 11.5 & 20.83 & 16.52 & 16.35 \\
\hline Average & 11.78 & 11.78 & 11.78 & 11.78 & 11.78 \\
\hline Deviation & -1.68 & -0.28 & 9.05 & 4.74 & 4.57 \\
\hline Part-time contract & 10.56 & 15.25 & 34.75 & 5.68 & 29.3 \\
\hline Average & 15.47 & 15.47 & 15.47 & 15.47 & 15.47 \\
\hline Deviation & -4.91 & -0.22 & 19.28 & -9.79 & 13.83 \\
\hline
\end{tabular}

Note: Pooled sample of all ESS respondents 2002-2010 (waves 1-5) in 16 countries (AT, BE, CH, DE, DK, ES, FI, FR, GB, GR, IE, IT NL, NO, PT, and SE); $N=146,596$. ESS=European Social Survey.

\section{Labor market outsiders and electoral choice within the working class}

The next step is to look at the electoral behavior of these groups to test the assumption that labor market outsiders constitute the "traditional-authoritarian-nationalist" working class constituency of right-wing populist parties. To this end, I compare logistic regressions of vote participation and right-wing populist voting (as opposed to voting for any other party or abstaining) for working class respondents in the eight countries in the cumulative ESS file that have more than 100 respondents declaring they voted for a right-wing populist party. All models contain the three main forms of post-industrial labor market risk that characterizes labor market outsiders. In addition, I introduce the three groups of globalization/modernization losers sequentially.

There are two main insights in Table 2. First, within the working class, labor market risk is strongly related to abstention, but not to right-wing populist voting. Both the experience of unemployment and a temporary contract clearly, consistently and substantially increase the probability that an individual will not participate in the election. Part-time work, by contrast, is not related to abstention. None of these forms of labor market vulnerability predicts the vote for the populist right. Hence-and this is the second main finding-among the working class, it is not the "objectively" most vulnerable who vote for the populist right. This is also consistent with the finding in Table 2 that low-skilled service workers tend to vote less, but do not tend to vote for right-wing populist parties over-proportionally. Rather, it is the routine/skilled manual workers that tend to support these parties more frequently. Finally, Table 2 also confirms that globalization losers (measured in terms of offshoreability) are clearly not the electorate of the populist right.

In sum, it appears clearly that labor market outsiders are not the main constituency of the populist right. There is no direct link between labor market vulnerability and the electoral choice of the workers most strongly affected by it. Rather, labor market outsiders tend to abstain from voting, and it is the skilled and routine manual working class (the traditional "insiders") that supports right-wing populist parties over-proportionally.

\section{Conclusion}

My findings in this short contribution resonate strongly with the ones by Bornschier and Kriesi (2013: 11ff), who investigate the working class vote for the populist right. They find that even within the manufacturing working class, "job insecurity and low education actually prevent individuals ... from participating, rather than making them vote for the extreme right" (2013: 22). Hence, labor market vulnerability does not explain right-wing populist voting. Rather, it is the 
Table 2. Determinants of Electoral Participation (Voting) and Right-Wing Populist Party Vote (Rpop) within the Working Class (Routine and Skilled Office, Manual and Service Workers)

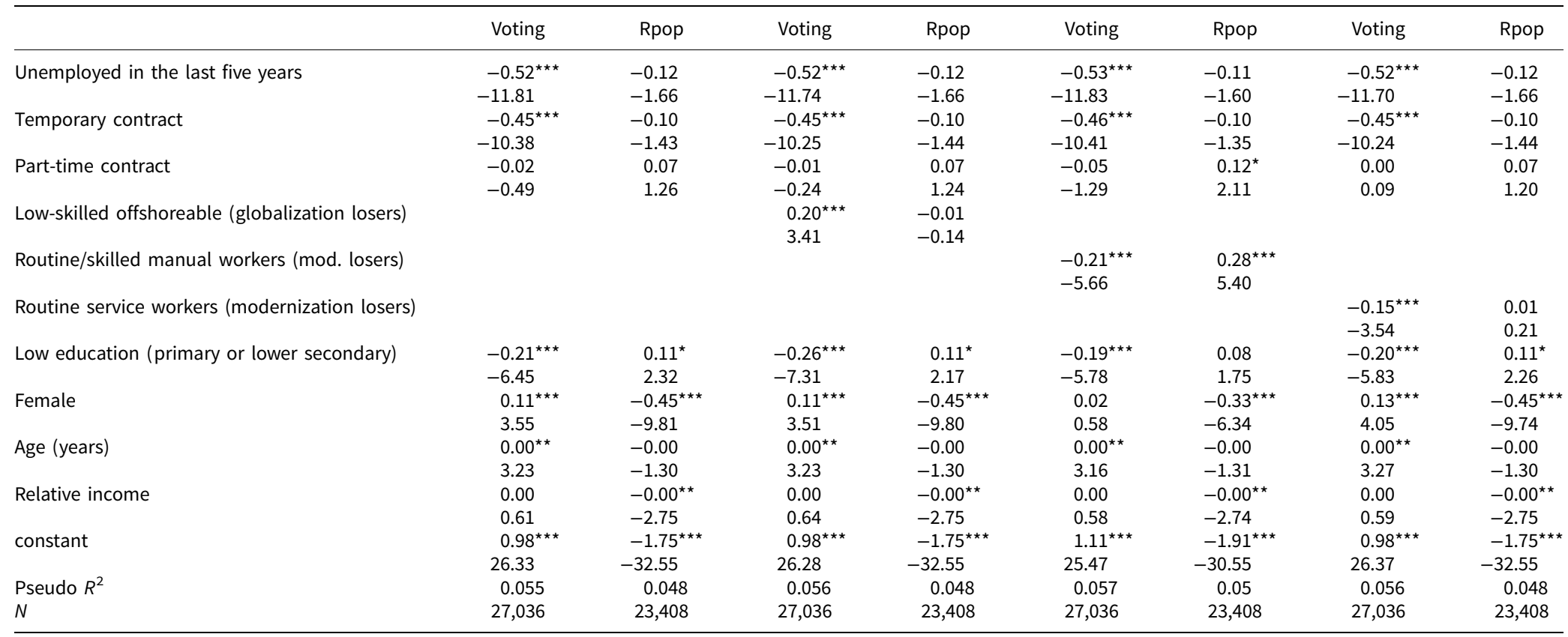

Note: Table shows the coefficients and $z$-values; effects of country dummies not shown.

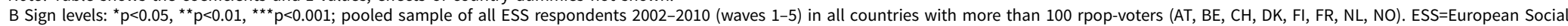
Survey. 
traditional manufacturing working class that supports these parties strongly. Several recent studies also find evidence that the actual experience of unemployment or occupational precariousness is unrelated to right-wing populist voting (Kurer 2017). All these studies come to the consistent conclusion that the right-wing populist vote is not a direct reaction to the experience of economic hardship. Bornschier and Kriesi (2013) suggest what they call a cultural mechanism to explain why the skilled manufacturing working class supports these parties most strongly: "while not being the worst-off social segment in post-industrial society, this group has experienced a relative decline as compared to the postwar decades, making it receptive to the culturalist appeals of the extreme right" (2013: 26).

The above findings highlight the importance of investigating further the (non-)mobilization of labor market outsiders. One key question for European political parties seems to be whether this growing group of voters can at all be mobilized and-if yes-which parties would most likely win their votes. This seems to be an open question, as recent research found that the preferences of service workers tend to align with those of the production workers on matters of immigration, but at the same time they hold more favorable views towards welfare, social investment, and cultural liberalism (Ares 2017).

\section{References}

Ares M (2017) 'Class Voting in Post-industrial Economies: A Comparative and Longitudinal Approach'. PhD Thesis Florence: European University Institute.

Betz H-G (1994) Radical Right-Wing Populism in Western Europe. New York: St. Martin's Press.

Bornschier S (2010) Cleavage Politics and the Populist Right. The New Cultural Conflict in Western Europe. Philadelphia: Temple University Press.

Bornschier S, and Kriesi H (2013) The Populist Right, the Working Class, and the Changing Face of Class Politics. In Jens Rydgren (ed), Class Politics and the Radical Right. New York: Routledge.

Burgoon B, and Fabian D (2010) Flexible employment, economic insecurity and social policy preferences in Europe. Journal of European Social Policy 20, 126-41.

Häusermann S (2010) The Politics of Welfare Reform in Continental Europe. Modernization in Hard Times. New York: Cambridge University Press.

Häusermann S, Kurer T, and Schwander H (2015) High-Skilled Outsiders? Labor Market Vulnerability, Education and Welfare State Preferences. Socio-Economic Review 13, 235-58.

Hooghe L, Marks G, and Wilson CJ (2002) Does Left/Right Structure Party Positions on European Integration. Comparative Political Studies 35, 965-89.

King D, and Rueda D (2008) Cheap Labor: The New Politics of "Bread and Roses" in Industrial Democracies. Perspectives on Politics 2, 279-97.

Kitschelt H (1994) The Transformation of European Social Democracy. Cambridge: Cambridge University Press.

Kitschelt H (1997) The Radical Right in Western Europe. A Comparative Analysis. Ann Arbor: Michigan University Press.

Kriesi H, Grande E, Lachat R, Dolezal M, Bornschier S, and Frey T (2008) West European Politics in the Age of Globalization. Cambridge and New York: Cambridge University Press.

Kurer T (2017) The Declining Middle: Political Reactions to Occupational Change. PhD thesis. Zurich: University of Zurich.

Lindvall J, and Rueda D (2014) The Insider-Outsider Dilemma. British Journal of Political Science 44, 460-75.

Lubbers M, Mérove G and Peer S (2002) Extreme Right-Wing Voting in Western Europe. European Journal of Political Research 41, 345-78.

Mughan A, Bean C, and McAllister I (2003) Economic Globalization, Job Insecurity and the Populist Reaction. Electoral Studies 22, 617-33.

Oesch D (2013) Occupational Change in Europe. How Technology and Education Transform the Job Structure. Oxford: Oxford University Press.

Rehm P (2011) Social Policy by Popular Demand. World Politics 63, 270-99.

Rehm P, Hacker J, and Schlesinger M (2012) Insecure Alliances: Risk, Inequality, and Support for the Welfare State. American Political Science Review 106, 386-406.

Rommel T, and Walter S (2017) The Electoral Consequences of Offshoring. How the Globalization of Production Shapes Party Preferences in Multi-Party Systems. Comparative Political Studies 51, 621-58.

Cite this article: Häusermann S (2020). Dualization and Electoral Realignment. Political Science Research and Methods 8 , 380-385. https://doi.org/10.1017/psrm.2018.48 